\title{
Reklāmas un sludinājumi laikrakstā "Tēvija" 1941. gadā kā vēstures avots
}

\author{
Advertisements in the Newspaper Tēvija in 1941 \\ as a Source of History
}

Ojārs Stepens, Mg. hist., Mg. art.

Latvijas Universitātes Vēstures un filozofijas fakultātes doktorants

Aspazijas bulvāris 5, Rīga, LV-1050

E-pasts: ojars.stepens@inbox.Iv

Lai gan parasti vēstures pētniecībā masu informācijas līdzekḷos publicētajiem sludinājumiem pievērš maz uzmanības, tie ir nozīmīgs informācijas avots, kas sniedz ziņas par pagātnes norisēm. Tie veido atsevišķu slāni mediju komunikācijā ar sabiedrību, ìpaši tādēl, ka bieži no tiem var gūt ziņas, kuras saistītas nevis ar "oficiālo viedokli", bet gan ar cilvēkiem patiešām aktuāliem sadzīves jautājumiem (pērk, pārdod, maina, izklaide u. c.). Tāpat sludinājumi atklāj saimnieciskās, politiskās un sabiedriskās dzīves norises. Raksta mērḳis ir analizēt reklāmas un sludinājumus Latvijā nacistu okupācijas varas izdotajā oficiālajā laikrakstā "Tēvija" 1941. gadā. Pētijuma hronoloǵiskais ietvars izvēlēts, ņemot vērā šãdus apsvērumus: 1941. gads bija laiks, kad Latvijā formējās nacistu okupācijas varas sistēma, vēlāk tā pastāvēja vairāk vai mazāk stabilā formā; tieši šajā laika posmā bija raksturīga padomju okupācijas laikā un karadarbībā bojāgājušo radinieku meklēšana ar sludinājumu palīdzību, ar holokausta īstenošanu saistītās nacistu antisemītiskās propagandas uzsākšana un izvēršana u. c. Minēto cēloṇu dẹl Latvijas iedzīvotāju ikdienas dzīvē šis laiks bija īpašs, un tas atspoguḷojas arī reklāmās un sludinājumos.

Atslēgvārdi: reklāmas, sludinājumi, vēstures avoti, nacistu okupācija.

Although often neglected in historical research, classifieds are an important source of information referring to past events. They form a distinct layer in media communication with the general public. Classifieds are particularly important since they can provide messages that are not rsubject to different types of the "official opinion", but rather reflect people's actual lives and concerns (buying, selling, exchanging goods, entertainment, etc.). Classifieds can also hint at ongoing economic, political and social developments. The purpose of the article is to analyse classifieds in the official newspaper Têvija issued by the Nazi occupation power in Latvia in 1941 as a source of historical information. The chronological framework of the research was 
chosen taking into account the following considerations: 1941 was the time when the Nazi occupation regime was formed in Latvia (whereas later the situation stabilized). 1941 also marked the period when such phenomena as the search for relatives killed during the Soviet occupation and war or launching and expansion of Nazi anti-Semitic propaganda related to the Holocaust rapidly gained importance. Consequently, this time period was of a particular consequence for the inhabitants of Latvia, and its specifics are also reflected in classifieds regarded as a historical source. Keywords: classifieds, advertisements, history sources, Nazi occupation.

\section{Problēmas izpēte Latvijas vēstures literatūrā}

Jāatzīst, ka aplūkotā problēma Latvijas historiogrāfijā pētīta maz, ir pētījumi par latviešu ikdienas dzīvi nacistu okupācijas laikā, par nacistu propagandu un ekonomisko politiku, kurus var izmantot, šajā rakstā iztirzātos jautājumus iekḷaujot plašākā Latvijas vēstures kontekstā. ${ }^{1}$ Atzīmējams ir apkopojošais Latvijas Otrā pasaules kara vēstures pārskats "Latvija Otrajā pasaules karā (1939-1945”,'ª̄pat nozīmīga ir vēsturnieku Edvīna Evarta un Jura Pavloviča monogrāfija "Ikdienas dzīve Latvijā nacistiskās Vācijas okupācijas laikā 1941-1945"3 un Kaspara Zeḷla monogrāfija "Ilūziju un baiḷu mašinērija. Propaganda nacistu okupētajā Latvijā: vara, mediji un sabiedrība (1941-1945)". ${ }^{4}$ Ir veikti pētījumi par preses izdevumu un preses vēsturi Latvijā, šeit var minēt Valsts pētījumu programmas "Nacionālā identitāte" projekta "Nacionālā identitāte un komunikācija" ietvaros izdoto rakstu krājumu "Latvijas preses vēsture: diskursi un identitātes" Ojāra Skudras redakcijā. ${ }^{5}$ Atsevišķus aspektus par nacistu okupācijas laika preses izdevumu izmantošanu, izplatot propagandu, rakstā "Karikatūra kā "kara ierocis": dažas tendences nacionālsociālistiskajā propagandā" ir pētījis vēsturnieks Dmitrijs Oḷehnovičs. ${ }^{6}$ Tēmai par preses izdevumu nozìmi nacistu okupācijas varas politikas veidošanā pievērsies arī vēsturnieks Arturs Žvinklis rakstā "Latviešu prese nacistiskās Vācijas okupācijas laikā". ${ }^{7}$ Preses izdevumu lomu nacistiskās okupācijas beigu posmā apskatījis K. Zellis pētījumā "Latviešu prese Kurzemē, 1944./45. gads". ${ }^{8}$ Savukārt attiecībā uz preses lomu nacistu okupācijas laika antisemìtisma ideologijas izplatīšanā var atzīmēt vēsturnieka Leo Dribina pētījumu "Antisemītisms nacistiskās okupācijas laikā izdotajā presē Latvijā (1941-1945)". ${ }^{9}$

Vairākos pētījumos pievērsta uzmanība tieši laikraksta "Tēvija" nozīmei nacistu okupācijas režīma politikas un propagandas formēšanā. Minētajā rakstu krājumā "Latvijas preses vēsture: diskursi un identitātes” iekḷauts arī Didža Bērziṇa pētījums "Latviešu identitātes konstrukcija laikraksta "Tēvija" propagandas materiālos: "mēs un viņi" diskurss (1941. gada jūlijs - 1942. gada janvāris)". ${ }^{10}$ D. Bērziņš ir pētījis arī laikraksta "Tēvija" izmantošanu nacistu antisemītisma propagandā okupācijas sākumposmā - rakstā "Nacistiskā antisemītisma propaganda laikrakstā "Tēvija" 1941. gada jūlijā: latviešu (līdz)dalības diskurss". ${ }^{11}$ Vēsturnieki K. Zellis un D. Oḷehnovičs veikuši kopīgu pētījumu par laikrakstā "Tēvija" publicēto karikatūru nozìmi nacistu propagandā, ${ }^{12} \mathrm{~K}$. Zellis publicējis rakstu par nacistu okupācijas sākuma posmā laikrakstā "Tēvija" nodrukāto lirikas darbu statistisko analizi. ${ }^{13}$

Tomēr jākonstatē, ka minētajā literatūrā sludinājumi un reklāmas kā viens no vēstures avotu veidiem nav pētīti. Arī reklāmas vispārējā vēsture Latvijā vēl joprojām ir lauks, kurā nepieciešama izpēte. ${ }^{14}$ 
Laikmeta politisko un sociālo norišu atspoguḷojums laikrakstā "Tēvija" 1941. gadā ievietotajos sludinājumos un reklāmās

İpaša nacistu okupācijas varas kontrolētu latviešu laikrakstu izdošana bija plānota jau pirms Vācijas uzbrukuma PSRS. ${ }^{15}$ Laikrakstus bija paredzēts pakḷaut stingrai cenzūrai. ${ }^{16}$ Vācijas karaspēkam ienākot Latvijā 1941. gada jūlijā, visu preses izdevumu kontroli pārnēema Vērmahta Rīgas propagandas nodaḷa (Propagandastaffel Riga). ${ }^{17}$ Jebkurus mēǵinājumus izdot neatkarīgus preses izdevumus okupācijas vara jau sākumā apspieda, bez tās kontroles izdevās izdot tikai vienu laikraksta "Brīvā Zeme” numuru 1941. gada 1. jūlijā Rīgā. ${ }^{18}$ 2. jūlijā Rīgas vācu komandants laikraksta izdošanu aizliedza. ${ }^{19}$

Realizējot iepriekšminētos norādījumus, okupācijas vara 1941. gada jūlijā uzsāka vairāku laikrakstu izdošanu. Pirmais nacistu okupētajā Latvijā iznāca Mārtina Vagulāna rediǵêtais laikraksts "Nacionālā Zemgale" 30. jūnijā Jelgavā. ${ }^{20}$ Nozīmīgākais no nacistu varas laikā izdotajiem laikrakstiem bija "Tēvija”, kas sāka iznākt 1941. gada 1. jūlijā Rīgā. ${ }^{21}$ Laikmeta vēsturiskās norises atspoguḷojās preses izdevumos ievietotajos sludinājumos.

Šajā pētījumā aplūkots, kā laikrakstā "Tēvija" publicētajās reklāmās un sludinājumos atklājas nosacìtas tēmas: laikmeta politiskie notikumi, stāvoklis saimnieciskajā dzīvē un kultūras norises. Laikā no 1941. gada jūlija līdz decembrim laikrakstā "Tēvija" tika publicēti apmēram 34000 sludinājumu. Pirmajos "Tēvijas" numuros jūlija sākumā nebija ievietots neviens sludinājums, 3. jūlija numurā bija 20 sludinājumi. To skaits pieauga no dažiem desmitiem jūlija vidū līdz vairākiem simtiem katrā laikraksta numurā līdz pat gada beigām. Šos sludinājumus var iedalìt vairākās grupās pēc tēmām. Pirmkārt, sludinājumi, kurus var vērtēt kā zināmā mērā politiskus, - te vispirms jāmin sludinājumi, kuros piederīgie ziņo par padomju varas laikā bojāgājušo bērēm, meklē padomju okupācijas varas un karadarbības laikā pazudušos radiniekus, tāpat arī kara laikā nozaudētās materiālās vērtības utt. Pie šis sludinājumu grupas var pieskaitīt arī nedaudzos nacistu varas iestāžu ievietotos sludinājumus, kuriem cita starpā varēja būt zināms propagandas uzdevums.

Otrkārt, sludinājumi par ekonomikas jautājumiem - tādi bija t. s. dzīvokḷu problēmai veltîtie sludinājumi. Padomju okupācijas vara ievērojami izpostīja Rīgas un citu pilsētu dzīvojamo fondu, bet karadarbība 1941. gadā radīja vēl nopietnākus postijjumus. Savukārt pēc Latvijas nonākšanas Vācijas okupācijā dạ̣a dzīvojamā fonda tika nodota okupācijas armijas un ierēdṇu rīcībā, līdz ar to nepieciešamība iegūt dzīvojamās telpas daudziem Latvijas iedzīvotājiem kḷuva ḷoti aktuāla.

Vēl viena tipiska problēma, kas atspoguḷojās arī sludinājumos, bija dažādu preču un materiālu trūkums. Padomju okupācijas varas uzsāktie plašie sociālekonomiskie eksperimenti lielā mērā sagrāva Latvijā ierasto ražošanas un tirdzniecības sistēmu, radot akūtu dažādu preču trūkumu. PSRS un Vācijas kara laikā ekonomikas attīstību kavēja kara postījumi. Arī Vācijas okupācijas vara uzsāka pārveidot Latvijas ekonomiku atbilstoši nacistu ideoloǵijas prasībām un jau no pirmajām okupācijas dienām ekspluatēja vācu kara vajadzībām ievērojamus Latvijas tautsaimniecibas resursus, kas agrāk bija pieejami privātam patērinam.

Cita sludinājumos skartā ekonomikas tēma bija darbaspēka pieprasījums. 1940.-1941. gadā padomju okupācijas varas politiskais terors skāra vairākus desmitus tūkstošu Latvijas iedzīvotāju, liedzot vinu darbaspēku izmantot tautsaimniecībā. Sākoties Vācijas un PSRS karam, darbaspēka zaudējumus papildināja ap $50000 \mathrm{uz}$ 
PSRS teritoriju evakuēto Latvijas iedzīvotāju. ${ }^{22}$ Upuru skaitu palielināja nacistu terors, kas 1941. gada vasarā vērsās pret t. s. bijušajiem padomju aktīvistiem, kad tika nogalināti ap 10000 Latvijas iedzīvotāju. ${ }^{23}$ Jau no pirmajām nacistu okupācijas dienām sāktais holokausts no tautsaimniecībā aktīvi iesaistīto cilvēku skaita izslēdza ap 70000 ebreju, kuri tika nogalināti, ieslodzīti geto un citādi represēti. Līdz ar to jaunu darbinieku meklēšana kḷuva par vienu no izplatītākajām sludinājumu tēmām. Kopumā tas atspoguloja Vācijas okupācijas varas ekonomisko politiku iekarotajās teritorijās, kur par galveno uzdevumu kḷuva resursu maksimāla izmantošana kara vajadzībām. ${ }^{24}$ Īpaša šīs politikas sastāvdaḷa, kas sevišḳi ietekmēja Latvijas iedzīvotāju uzskatus par vācu okupācijas varu, bija lēmums ātrāk sākt izmantot Latvijas tautsaimniecības resursus, cik iespējams, nemainot padomju okupācijas laikā ieviesto saimniekošanas sistēmu: pārņemt vācu kontrolē padomju nacionalizētos uzñēmumus, nevis atdot tos bijušajiem ipašniekiem utt. ${ }^{25}$

Bez jau minētajām grupām no "Tēvijā" ievietotajiem sludinājumiem nodalāmi tādi, kurus tematikas ziņā nosacīti var iekḷaut sadaḷā "kultūras dzīves norises". ${ }^{26}$ Pirmām kārtām tādi ir paziṇojumi par izklaides un sabiedrisko pasākumu norisi, tie l,auj gūt ieskatu to pasākumu klāstā, kādi Latvijas iedzīvotājiem bija pieejami kara laikā. Šeit, protams, izcelas dažādi pasākumi un sarīkojumi, kuri bija specifiski tieši nacistu okupācijas laikam (piemēram, organizācijas “Tautas palīdzība” rīkotie). No kopējā sludinājumu klāsta nodalāmi arī tie, kas informē par Latvijas kino un teātru repertuāru un ḷauj izpētìt, kāda vieta to programmās bija atvēlēta nacistu ideologiijas propagandai. Tāpat jānodala sludinājumi, kas reklamē tiešus nacistu okupācijas varas propagandas pasākumus, piemēram, aicinājumi iegādāties dažādus nacistu propagandas materiālus.

\section{0.-1941. gada upuru un zaudējumu tēma}

Pirmais sludinājums, kurā paziņots, ka Atis Jaunzems un Jānis Fridrihs Jaunzems miruši "upura nāvē Salaspili 29. jūnijā, 1941", ievietots "Tēvijas" 3. jūlija numurā. ${ }^{27}$ Sludinājumi saistībā ar padomju okupācijas laika terora upuriem vai karadarbības laikā bojāgājušajiem tika publicēti visu gadu, to skaits ievērojami samazinājās tikai novembrī. Jūlija pirmajā pusē šî tēma dominēja sludinājumu kopējā masā. Jau minētajā "Tēvijas" 3. jūlija numurā, piemēram, kopumā bija ievietoti 20 sludinājumi, no tiem upuru tēmai veltīti $12 ;^{28}$ no 5 . jūlija numurā publicētajiem sludinājumiem (61) šai tēmai veltitti 27. ${ }^{29}$ Pamatā var izškikirt tuvinieku pazin,ojumus par piederīgo bojāeju padomju okupācijas laikā un sludinājumus, kuros iedzìvotāji aicināti sniegt ziņas par padomju okupācijas laikā pazudušajiem. Tā “Tēvijas" 12. jūlija numurā publicēti 132 sludinājumi, no tiem 14 ir pazinojumi par padomju terorā bojāgājušo bērēm un trīs lūgumi palīdzēt atrast pazudušos. ${ }^{30}$ 5. augusta "Tēvijas" numurā publicēti sludinājumi par padomju terorā nogalinātu četru cilvēku bērēm un 46 sludinājumi par pazudušu personu meklēšanu. ${ }^{31}$

Kā tipiski šādu sludinājumu paraugi turpmāk citēti paziņojumi no laikraksta jūlija un augusta numuriem. 14. jūlijā "Tēvija” publicēja paziņojumu par padomju terora laikā nogalinātā Lāčplēša Kara orden,a Voldemāra Brašes nāvi: "Mūsu mīlotais Voldemārs Braše [...] nošauts no komunistiem Rigas centrālcietumā š. g. 28. jūlijā. Sieva un piederīgie." Turpat publicēts paziñojums par ārsta Teodora Volframa nāvi padomju terora laikā: "Š. g. jūnijā žìdu un komunistu noslepkavots ärsts Teodors Volframs bij. Liepājas slimnicas direktors. Apbedits Liepājas Centrālkapsētā. Dzilāās sērās piederīgie." ${ }^{32}$ 11. augusta numurā ievietots sludinājums vēstīja par Oskara Henninga nāvi: "Mūsu 
mīlo Oskaru Henningu š. g. 28. jūnijā noslepkavoja komunistu bendes. Apglabāts š. g. jūlijā Rīgā, Meža kapos. Sērojošie piederīgie." ${ }^{33}$ Tipisks bezvēsts pazudušo meklēšanas sludinājums ir arī 14. jūlija "Tēvijas" numurā ievietotais paziņojums par Jāṇa Šmita un Konstantīna Kalniṇa meklēšanu: "Kas ko zinātu par Jāni Šmitu no Ogres pag. Emmas dzirnavām, apc. 25. VI un aizvestu uz Madonas cietumu, un Konstantinu Kalninu no Liepkalnes pag., apc. 22. VI, pazinot Marijas ielā 82-84, d\%. 80, E. Kanai." 34 Savukārt 23. augusta numurā radinieki meklēja bezvēsts pazudušo karavīru Kārli Arvēdu Jansonu: "Ja kāds ko zinātu par bij. Zenitbaterijas pulka 5. baterijas šoferi Kārli Arvēdu Jansonu [...] lūdz pazinotot Ogresgala pag. Puriņos M. Jansonam."35 Turpmākajos laikraksta numuros šādu sludinājumu skaits samazinājās, tomēr neizzuda līdz pat gada beigām. "Tēvijas" 11. decembra numurā ievietoti pieci, ${ }^{36}$ bet 27 . decembra numurā trīs sludinājumi, meklējot padomju okupācijas laikā pazudušos. ${ }^{37}$

Vairākos pazinojumos lūgts līdzpilsoņus palīdzēt atrast kara laikā pazudušās mantas - daudzi iedzīvotāji cerēja atkal atsākt miera laika dzīvi. Jāatzīmē, ka mēginājumi ar sludinājumu palīdzību atrast kara laikā pazudušās mantas ar laiku skaitliski samazinājās, tomēr ik pa brīdim tika atkārtoti līdz pat gada beigām. Visbiežāk ar sludinājumu palīdzību meklēti pazuduši zirgi un transportlīdzekḷi, liela daḷa no tiem izrādījās iznīcināti karadarbības laikā. "Tēvijas" 5. augusta numurā ievietots Jelgavas lombarda sludinājums, meklējot pazudušās materiālās vērtības: "Jelgavas pilsētas lombardam komunisti nolaupijuši zelta priekšmetus un pulksten̦us. [...] Atrašanas gadijumā zinot lombardam Jelgavā." ${ }^{38} 24$. jūlijā ievietots viens no pirmajiem sludinājumiem par karadarbības laikā pazuduša transportlīdzekḷa meklēšanu: "Kas ko zinātu par vieglo auto Mercedes Benz [...], lūdz pazinot Dzirnavu ielā 67-12." "39 "Tēvijas" 11. augusta izdevumā īpašnieks meklēja pazudušu Ford markas automašīnu: "Pret pateicibas algu kas varētu uzrādìt bolšseviku aizvestā tumši zilā "Ford" limuzina 1930. g. mod., braukš. Nr. 727, [...] atrašanās vietu, sniegt ziñas par to rakst. A. Bētinam, Madlienas aptiekā." ${ }^{40}$ Reizēm norādīta atradēja atlīdzības summa, piemēram, sludinājumā 27. decembrī, meklējot pazudušu zirgu: "RM 60. - maksāju tam, kas varētu uərādìt š. g. 23. jūnijā lielinieku Madonā rekvizēto zirgu. 5. g. v., bèru. 163 centm. augstu, krēpes un aste melnas [...] Ziñot A. Salinam Meirānu pag. [...]" Turpat ievietots sludinājums, kas apliecina, ka reizēm zudušo izdevās atrast - Rēzeknes pilsētas valdes paziņojums, ka tiek meklēts īpašnieks jūnija beigās pamestam zirgam, ko "atstājis kāds ṣ̌ūtnieks, kuram vajadzējis vest tālāk kādu bēgošās Sarkanarmijas komandieri, un pats aizmucis". ${ }^{41}$

Šìs grupas sludinājumi sniedz interesantu informāciju par Latvijas iedzīvotāju dzīvi okupāciju varas maiņas laikā. Šādu sludinājumu īpatsvars visu 1941. gadā publicēto sludinājumu vidū nav liels, tie veido tikai mazu daḷu no sludinājumu kopskaita, tomēr tiem ir izteikta informatīvā spriedze. Tāpat jāatzīmē sakritība, ka minētie sludinājumi lielākoties publicēti perioda sākumā un kopējā sludinājumu masā 1941. gada jūlija sākumā ir dominējošie.

\section{Nacistu okupācijas režìma politika un propaganda}

Sludinājumu, kas saistīti ar nacistu propagandu, nav daudz. Protams, tas bija l,oti specifisks propagandas veids. Nacistu propaganda sludinājumos galvenokārt izpaudās dažādos aicinājumos iedzīvotājiem iegādāties nacistu aǵitācijas materiālus un varas simbolus. Viens no šādiem sludinājumiem ievietots laikraksta "Tēvija" 12. jūlija numurā: "Lielvācijas karogi katrā daudzumā dabūjami firmā "Gentleman" 
Kalk, ielā 22/24. [...]"42 Savukārt laikraksta 24. jūlija izdevumā iedzīvotājiem bez Vācijas karogiem piedāvāts iegādāties arī Latvijas karogus: "Lielvācijas un Latvijas karogus gatavo E. Junde. Giertrūdes ielā 20-20 [...]." ${ }^{43}$ Bez karogiem aktuāls bija arī citu propagandas materiālu piedāvājums, piemēram, sludinājumā "Tēvijas" 19. jūlija numurā: "Lielvācijas vadoña Ādolfa Hitlera gímetnes dabūjamas rakstāmlietu veikalā Blaumaņa ielā 38-40."44 Aicinājumi iegādāties nacistu aǵitācijas materiālus nav vienīgie sludinājumi, kuros izpaudās nacistu propaganda, piemēram, 24. jūlija numurā publicēts paziņojums par Vācu muzeja atklāšanu Rīgā: "Vācu Mūzejs Rìgā. Pirmais mūzejs, kas atvērts no padomju virskundzibas atbrivotajās teritorijāas, ir Vācu mūzejs Rīgā. Tanī redzami vācu vēstures pieminekli Baltijā [...]." ${ }^{45}$

Vairākos sludinājumos izpaudās arī nacistu uzsāktā antisemītisma politika, vēršanās pret ebrejiem un vinu vajāšana. Piemēram, "Tēvijas" 8. novembra numurā ievietots kādas grāmatnīcas Rīgā, Marijas ielā, sludinājums par dažādu grāmatu u. c. materiālu iepirkšanu: "Grāmatas un pastmarkas pērk katrā vairumā un visās valodās [...] Žìdu un žìdu izdotas grāmatas nepērk." ${ }^{46}$ Pret ebrejiem vērsto nacistu okupācijas varas politiku apliecina arī pazinojumi par dažādu ebreju organizāciju likvidāciju. Tā "Tēvijas" 1. novembra numurā ievietots sludinājums par Ebreju sporta biedrības likvidāciju: "Valsts statistiskās pārvaldes sporta pulcina, Rïgas sporta putnkopïbas pārraudzïbas b-bas, Rigas šacha biedribas senioru kluba un Žìdu sporta biedrïbas "Hakoah" likvidators uzaicina augšminēto likvidējamo biedrïbu debitorus, kreditorus [...] pieteikties likvidatoram [...]." ${ }^{47}$

Tāpat no sludinājumiem varēja uzzināt par dažādu padomju varas izveidotu organizāciju likvidāciju. "Tēvijas" 4. septembra numurā ievietots sludinājums par Latvijas Padomju rakstnieku savienības likvidāciju: "Rakstnieku savienibas likvidators uzaicina visas personas un iestādes, kam no Rakstnieku savienïbas kas pienākas [...] pieteikt savas prasïbas un nokārtot savas saistibas mēneša laikā [...]." 48

Minētās grupas sludinājumi dod būtisku ieskatu nacistu okupētās Latvijas dzīvē. Attiecībā uz sludinājumiem par nacistu simbolikas un propagandas materiālu tirdzniecību jāpiezīmē, ka lielā mērā tiem bija raksturīga informatīva, nevis propagandas funkcija, jo propagandas izplatīšanai piemērotāki bija citi līdzekḷi (plakāti, kino u. c.). Šāda tipa sludinājumu īpatsvars kopējā skaitā nav liels, kaut gan tie atkārtojas visā aplūkojamajā laika posmā.

\section{Kara laika ekonomiskās problēmas. Dzīvokḷu jautājums}

Nepieciešamība atrast dzīvesvietu daudziem Latvijas iedzīvotājiem kara laikā kḷuva loti aktuāla. "Tēvijā" pirmais sludinājums par dzīvokḷa meklēšanu ievietots jau 3. jūlijā: "Istabiñu klusā giimenē meklē nedzēr., nesmēk,. kungs [...]." ${ }^{49}$ Gada pēdējos mēnešos tomēr sludinājumu skaits samazinājās. "Tēvijas" 25. jūlija numurā ievietots sludinājums: "Mazu dzīvokli 2 istabas, Doma l. tuvumā meklè vientula persona. [...]"50 Viens no pēdējiem sludinājumiem, meklējot dzīvojamās telpas, ievietots "Tēvijas" 27. decembra numurā: "Students - laucinieks meklē èrtu mēbelētu istabu. [...]"51

Īpašu interesi izraisa sludinājumi, kas liecina par nacistu okupācijas varas politiku. 1941. gada vasarā un rudenī, veidojot okupācijas administrāciju, Latvijā iesūtīja vairākus tūkstošus vācu ierēdṇu, tāpat dzīvojamās platības bija nepieciešamas okupācijas karaspēka virsniekiem. Jāatzīmē, ka ne vienmēr sludinājumos tika norādīts, ka dzīvokli meklē tieši okupācijas varas ierēdnis, tomēr par to lauj spriest izmantotais formulējums "dzīvokli meklē valsts vācietis", piemēram, sludinājumā "Tēvijas" 22. augusta numurā: "Mēbelētas istabas vai visu dzìvokli, 
eventueli atsevišḳu mājinu centrā vai klusā solidā rajonā [...] vēlas ìrēt valsts vācietis ilgākam laikam [...]." ${ }^{52}$ Līdzīgs sludinājums arī 10. septembra numurā: "Valsts vācietis meklē [...] 2 gaišas, loti labi mēbelètas istabas ar apkalpošanu un visām èrtibām [...]." ${ }^{53}$ Tāpat arī 21. oktobra numurā: "Mēbelètas istabas steidzami meklē iebraucēju - valstsvāciešu ierēdṇu vajadzībām ilgākam laikam. [...]"54 Viens no pēdējiem šādiem sludinājumiem ievietots "Tēvijas" 8. decembra numurā: "Mēbelētas istabas steidzami meklē valstvāciešu-iebraucēju vajadzībām." 55

Minētā sludinājumu grupa atspoguḷo būtisku problēmu kara laika sadzīvē, jo tā veido apmēram trešdal̦u no saimnieciskajai dzīvei veltītajiem sludinājumiem. Lai gan perioda sākumā šādu sludinājumu ir vairāk, tie parādās arī turpmāk. Savukārt sludinājumu, kuros okupācijas varas pārstāvji meklē dzivokḷus, vairāk ir perioda sākumā (jūlijā, augustā, septembrī), kad nacisti veidoja iekaroto teritoriju pārvaldi. Vēlāk to skaits ievērojami samazinās - tas skaidrojams ar nacistu pārvaldes sistēmas stabilizēšanos, tāpat arī ar ievērojamu apdzīvojamo platību (tai skaitā holokaustā iegūto) nonākšanu okupācijas varas kontrolē, kas l̦āva uzsākt centralizētu tās izmantošanu nacistu ierēdṇu vajadzībām.

\section{Karalaika ekonomiskās problēmas. Preču deficīts}

Vēl viena karalaika problēma bija dažādu preču un izejmateriālu trūkums. Vācijas okupācijas vara Latvijas tautsaimniecības resursus jau ar pirmajām dienām izmantoja kara vajadzībām. Laikrakstos parādījās vācu iestāžu un privātfirmu sludinājumi, meklējot iespējas iepirkt dažādus materiālus un resursus. Ja veikalos brīvi iegādāties vajadzīgās preces bija grūti, par vienu no risinājumiem kḷuva savstarpēja preču apmaiņa starp iedzīvotājiem, un tai noderēja arī sludinājumi laikrakstos. Jau "Tēvijas" 3. jūlija numurā ievietots sludinājums: "Stikla lūžñus pērk katrā daudzumā stiklu fabrika Narvas ielā 2."56 "Tēvijas" 9. oktobra numurā ievietots kādas vācu firmas sludinājums: "Lielāka Lielvācijas firma meklē pirkt vai ìrēt 3-4 transporta automobilus jaunus vai lietotus." ${ }^{57}$ Raksturīgi arī sludinājumi, kas liecina par iedzīvotāju mēǵinājumiem atjaunot privāto uzṇēmējdarbību, bet tam bija nepieciešams iegādāties darbarīkus un materiālos resursus. 25. jūlijā sludinājumā “Tēvijā" meklēti izejmateriāli ražošanas vajadzībām: "Atsperu matračus, lietotus, pērk Blaumaña ielā 10 taps. darbnīcā." 1 1. novembra "Tēvijā" ievietots paziņojums: "Pērkam apǵērbus, velu, traukus un c. mantas, Adolfa Hitlera (Brīvibas) ielā 42 [...]"59 Laikraksta 9. oktobra numurā ievietots sludinājums: "Pērk kartupel̦us, saknes, dārzājus lielos vairumos Rīgas pilsētas Sociālās nodrošināšanas pārvaldes Centrālā produktu noliktavā Rīgā, Centrāltirgū [...]"60 Pirkšanas un pārdošanas sludinājumi bieži liecināja par mēǵinājumiem, izpārdodot dažādas privātās mantas, iegūt nepieciešamos naudas līdzekḷus. "Tēvijas” 27. decembra numurā ievietots sludinājums: "Rìgas pilss̄tas lombarda veikals M. Ķēniņu ielā 8, [...] pērk un pieñem pārdošanai komisijā lietotas drēbes, vel̦u, mēbeles daž. citas mantas."61 Savukārt laikraksta 20. septembra numurā publicēts paziņojums: "[Pērk] Uzvalka drēbi vai uzvalku vid. auguma." ${ }^{62}$ 6. decembrī kāda ğimene ievietojusi sludinājumu: "Pārdod lietotas dāmu, bērnu galošas, botes un kurpes. 33.-38. nr., 1 dāmu un 1 bèrnu mèteli. 12 g. v. Skolas ielā 25-22. I stāvā, sestdien no 16-19. Uzpircējiem nenākt."63

Dažādu preču tirdzniecība veido lielāko daḷu no saimnieciskajai dzīvei veltītajiem sludinājumiem - aptuveni vienu trešdaḷu. Tie atspoguḷo situāciju, kad preču trūkumu veikalos iedzīvotāji centās pārvarēt, tirgojoties savā starpā. Šādu sludinājumu skaits ir apmēram vienāds visā periodā. 
Tas liecina, ka preču deficīts bija pastāvīga problēma, ko nespēja novērst okupācijas varas pretpasākumi - kartiṇu ieviešana, propaganda u. c.

\section{Karalaika ekonomiskās problēmas. Darbaspēka tēma}

Viena no aktuālākajām sludinājumos skartajām tēmām bija darbaspēka pieprasījums un piedāvājums. Raksturīga laikmeta iezīme bija nepieciešamība pēc dažādiem speciālistiem ar vācu valodas zināšanām tādi bija vajadzīgi nacistu okupācijas varas iestādēm un arī privātuzṇēmumiem. "Tēvijas" 28. augusta numurā ievietots sludinājums: "Ādažu pagasta valdei vajadzīgs kancelejas ierēdnis(ne) vācu valodas pratējs(ja). Vēlama prakse pašvaldības darbā. Piet. rakstiski lidz š. g. 2. septembrim, iesniedzot isu dzìves aprakstu [...]"64 Līdzīgu sludinājumu "Tēvijas" 26. novembra numurā ievietojusi Smiltenes pagasta valde: "Smiltenes pagasta valdei, Valkas aprinkīi, vajadzīgs iestrādājies kancelejas ierēdnis-ne, kas pārvalda (mutiski un rakstiski) vācu valodu un ir strādājis kancelejas darbus. Personām, kas vēlas ieñemt šo amatu, lūgumi ar dzìves aprakstu un dokumentiem par izglīīibu, veselïbas stāvokli, lìdzšinējo praksi un politisko uzticamïbu iesūtāmi pagasta valdei lidz š. g. 29. novembrim. [...]"65 Vācu valodas zināšanas bija nepieciešamas arī vienkāršāku darbu veicējiem. "Tēvijas" 2. decembra numurā ievietots sludinājums, ka tiek meklētas virtuves strādnieces: "2 jaunas meitenes, latvietes, vēlams, kas drusku prot vācu valodu, vajadzìgas par palìdzēm virtuvē un pie istabām. Pieteikties Rotas kantorī, Blaumaña ielā 38/40."66

Kara sākuma juku laikos daudzi uzņēmumi bija spiesti pārtraukt darbību, tomēr tie centās, cik iespējams, saglabāt savus strādniekus, tos nosūtot bezalgas atvalinājumos, lai, situācijai stabilizējoties, varētu atsākt darboties. Bieži strādniekus okupācijas vara nosūtīja uz laukiem ražas novākšanas darbos, un rudenī tie atgriezās darbā savos uzṇēmumos. 19. jūlijā laikrakstā “Tēvija” Rīgas šîfera fabrika ievietojusi šādu sludinājumu: "Rīgas šifera fabrikas strādniekiem atvalıinājumi tiek pagarināti lìdz š. g. 27. jūlijam ieskaitot." ${ }^{67}$ Par saimnieciskās dzīves stabilizēšanos 1941. gada otrajā pusē, kad karadarbība aizvirzìjās prom no Latvijas, liecina arī pieaugošs skaits sludinājumu, ka tiek meklēti darbinieki, piemēram, 7. jūlijā: "Telefona liniju atjaunošanas darbiem Rìgas apkārtnē un provincē vajadzīgi vadu licēji. Pieteikties 4. telegrafa un telefona rajonā." ${ }^{68}$ Vēlāk jaunus darbiniekus sāka meklēt arī lielāki uzṇēmumi, kuri atjaunoja un, saṇēmuši okupācijas varas pasūtījumus, pat paplašināja savu darbību. 22. augustā jaunus strādniekus meklēja Rīgas rauga un liķiera fabrika: "Strādnieki, vajadzìgi Rìgas rauga un liksiera fabr. Rīgā, Ganību dambì [...]"69 Jaunus darbiniekus pēc kara sākuma juku laika meklēja arī daudzas pašvaldības institūcijas. "Tēvijas" 27. septembra numurā ievietots Mērsraga pagasta valdes sludinājums: "Mērsraga pagasta valdei Talsu apriņ̧ī vajadzīgs pagasta sekretārs. Pieņemšana š. g. 2. oktobrī. Lūgumi lìdz ar dokumentiem par izglītibu, sekretāra tiesībām, lìdzšinējo darbỉbu un vietējās policijas atsauksmi iesūtāmi pagasta valdei lìdz minētai dienai."70

Arī šīs grupas sludinājumi veido apmēram trešdaḷu no saimnieciskajai dzīvei veltìtajiem sludinājumiem. Vairāk to ir perioda sākumā (jūlijā, augustā, septembrī) - tas saistāms ar karadarbības izraisìto saimniecisko grūtību pakāpenisku pārvarēšanu, tomēr šādi sludinājumi publicēti arī turpmāk.

\section{Kultūra un izklaide}

Bez iepriekš aplūkotajām vēl viena sludinājumu tēma ir kultūra un izklaide dažādas reklāmas un paziņojumi par kultūras, izklaides un sabiedrisko pasākumu 
rīkošanu. Starp tiem bija arī pasākumi, kas saistīti ar nacistu okupācijas režīma propagandas izplatīšanu. Pirmajos "Tēvijas" numuros jūlija sākumā sludinājumu par kultūras un izklaides pasākumiem praktiski nebija. Karadarbībai aizvirzoties prom no Latvijas teritorijas un nacistu okupācijas pārvaldei nostiprinoties, okupētajā Latvijā zināmā mērā atjaunojās stabila sadzīve un līdz ar to arī kultūras dzīve. Jau jūlija beigās un augustā savu darbību bija atsākuši kinoteātri, teātri, muzeji un citas kultūras iestādes. Vieni no interesantākajiem ir tie sludinājumi, kuri liecina par nacistu varas propagandas pasākumiem, piemēram, "Tēvijas" 12. decembra numurā: "Vācu armijas pirmais lielkoncerts par labu vācu Ziemas palìdzỉbai un latviešu Tautas palïdzïbai. Svētdien, 1941. gada 14. decembrī Virsnieku klubā (Latviešu Biedrïbas namā) [...]"'11

Tomēr visvairāk par okupācijas režīma propagandu liecina sludinājumi ar Rīgas kinoteātru repertuāru 1941. gada vasarā un rudenī. ${ }^{72}$ 14. jūlijā laikrakstā ievietots sludinājums: ${ }^{73}$ "Kinoteātris "Renesanse" [...] "Vācijas uzvaras gājiens"."74 Skatītājiem bija paredzēts demonstrēt dokumentālo kinožurnālu par Vācijas armijas uzvarām frontē. 25. jūlijā laikrakstā atkal ievietots sludinājums par šīs filmas demonstrēšanu, šoreiz kinoteātros "AT", "Aina", "Liesma" un "Renesanse". ${ }^{75}$ Vienlaikus šajā sludinājumā minēts, ka kinoteātrī Splendid Palace tiek rādīta antisemìtiskā nacistu propagandas filma "Žīds Zīss". ${ }^{76}$ Arī sludinājumā "Tēvijā" 16. augustā skatītājiem piedāvātas nacistu propagandas filmas. ${ }^{77}$ Kinoteātrī "AT" - dokumentālās filmas "Stalina līnijas pāriešana", "Berlīne - Olimpiādes pilsēta", "Mūsu Zēni""78 un "Vācu ieroču kaltuves". ${ }^{79}$ 27. oktobrī sludinājums laikrakstā "Tēvija" piedāvāja skatītājiem šādas nacistu propagandas filmas ${ }^{80}$ - "Padomijas un angḷu sagraušana", "Veselīga jaunatne - spēcīga tauta", "Mūsu bērni - mūsu nākotne", "Vācijas ieroču kaltuves", "Kad vīri aizcel̦o", ${ }^{81}$
"Ugunskristības" un kinožurnālu "Nedēḷas apskats".

Bez propagandas filmām plašs bija arī mākslas filmu piedāvājums. Raksturīgi, ka nacistiskās okupācijas apstākḷos lielākā daḷa Latvijā izrādīto filmu bija vācu ražojums. 12. jūlijā Rīgas kinoteātros piedāvājumā bija ${ }^{82}$ drāma "Bel Ami"83 un piedzīvojumu filma "Kongo ekspresis". ${ }^{84}$ 25. jūlijā - "Bel Ami". 18. augustâ̄ ${ }^{85}$ - ASV mākslas filma "Kāzu nakts", ${ }^{86}$ čehu filmu "Julika", 87 ASV filmas "Pagājušās nakts meitene", 88 "Mīlu nemuito"89 un "Operas balle"..$^{90} 15$. septembrīị - "Hallo, Janine", 92 "Bel Ami", "Kāzu nakts", "Nevainīgā mīḷākā", ${ }^{93}$ "Kriminālkomisārs Eiks", ${ }^{94}$ "Operas balle", dokumentālā filma "Iglu mūžīgā klusēšana", ${ }^{95}$ "Neskati vīru no cepures", ${ }^{96}$ "Deju virpulī”. ${ }^{97} 22$. septembrīis - "Deju virpulī", "Hallo, Janine", "Operas balle", "Deju virpulī”, "Iglu mūžīgā klusēšana", "Neskati vīru no cepures", "Nevainīgā mīịākā", "Pandūrs Trenks", 99 "Ciema mūzika", 100 "Kāzu nakts", "Mūsu Zēni".

Bez kino piedāvājuma sludinājumi laikrakstos l̦auj spriest arī par citiem tobrīd pieejamiem izklaides pasākumiem. Līdzīgi kā kino, arī teātri 1941. gada vasarā un rudenī ar sludinājumu palīdzību regulāri informēja publiku par savu repertuāru. 25. jūlijā Dailes teātris Rīgā laikrakstā "Tēvija" ievietoja sludinājumu, piedāvājot Rūdolfa Blaumaṇa "Trīnes grēkus". Rīgas opera tai pašā laikā reklamēja izrādes "Čigānu barons" un "Karmena”. ${ }^{101}$ 31. jūlijā Dailes teātris atkal piedāvāja izrādi "Trīnes grēki", bet Rīgas opera - izrādi "Čigānu barons" un baleta vakaru. ${ }^{102} 25$. augustā Dailes teātra sludinājums aicināja uz izrādēm "Burvju liesma" un "Trīnes grēki”, Rīgas opera piedāvāja izrādes "Grāfs Luksemburgs", "Masku balle", "Gulbju ezers", "Čigānu barons" un "Aīda". ${ }^{103}$ 26. novembrī Dailes teātris reklamēja izrādes "Jūras vilki" un "Trīnes grēki", Rīgas opera - operas "Baņuta", opereti "Čigānu barons" un operu "M-me Butterfly". ${ }^{104}$ 2. decembrī Dailes teātris 
piedāvāja izrādes "Jūras vilki" un "Maija un Paija", Rīgas opera - operu "Banuta", baletu "Rozes gars" un operu "Skrejošais holandietis". ${ }^{105}$ Rīgas Filharmonija 31. jūlijā sludinājumā piedāvāja Marisa Vētras un Ādolfa Kaktina koncertu: "Sestd., 2. augustā plkst. 19 Mariss Vētra, Ādolfs Kaktiņš dziedās Franz Schubert un Emila Dārziña dziesmas. Pie klavierēm L. Garūta."106 26. septembrī reklāma "Tēvijā" informēja, ka Doma baznīcā 28. septembrī notiks "Bacha koncerts [...] Piedalās: V. Kačalovs (ērǵeles), A. Teichmanis (čello)". ${ }^{107}$

Ar sludinājumiem laikrakstā "Tēvija" savus pasākumus regulāri reklamēja arī Rīgas cirks. Sludinājums 25. jūlijā vēstīja: "Cirks Merkel̦a ielā sākot [...] ar 26. jūliju, ikvakarus pl. 18.30, sniegs interesantu programmu, kurā, dalibu n,ems: artisti, zirgi, suni, lauvas un lāči [...]." ${ }^{108}$ 2. oktobrī Rīgas cirks aicināja uz "Ziemas sezonas atklāšanu. Programmā Rob. Cimzes trupa un motocikls cirka arēnā". ${ }^{109}$ Savus sludinājumus "Tēvijā" regulāri ievietoja arī Rīgas hipodroms, varietē teātris Frasquita un citi. Frasquita, piemēram, 1. novembrī piedāvāja plašu programmu: "Šodien jaunā lielā novembra programma ar 26 pirmklasigiem numuriem [...]."110

Kultūras dzīvei veltīto sludinājumu ir l,oti daudz, apmēram trešdạ̣a no visiem sludinājumiem. Aplūkojamā perioda sākumā (jūlijā) to ir relatīvi mazāk, bet turpmāk to skaits pieaug. Šie sludinājumi sniedz informāciju par plašu kultūras norišu klāstu - kino, teātri, mākslas izstādēm, dažādiem sarīkojumiem utt. Spriežot pēc sludinājumu skaita un tajos pieejamās informācijas, aplūkojamajā periodā Latvijas kultūras dzìve bija intensīva un bagāta.

\section{Secinājumi}

Vēstures izpētei ir pieejami dažādi informācijas avoti, to skaitā var minēt arī reklāmās un sludinājumos iekḷautās ziṇas, konkrēti - nacistu okupācijas varas perioda sākumā, 1941. gadā, laikrakstā "Tēvija" publicētās reklāmas un sludinājumus. Izanalizējot tajos iekḷauto informāciju, iespējams iegūt ziṇas par attiecīgā laika posma Latvijas iedzīvotāju dzīvi.

Var izškirt vairākas sludinājumu tēmas. Aplūkojamā perioda sākumā - 1941. gada vasarā - raksturīgi sludinājumi, ar kuru palīdzību tika meklēti padomju okupācijas un karadarbības laikā bojāgājušie radinieki. Nākamā lielākā sludinājumu un reklāmu grupa sniedz informāciju par Latvijas iedzīvotāju sadzīves problēmām nacistiskās okupācijas laika sākumā. Vispirms jāmin ekonomiskās attīstības īpatnības, kas raksturīgas nacistu okupācijas posmam - preču deficīts tirdzniecībā, dzīvojamo telpu trūkums, tāpat arī dažādu uzṇēmumu darbībai nepieciešamo izejmateriālu un resursu iepirkumi. Vēl vienu sludinājumu un reklāmu bloku veido ziņas par kultūras un izklaides pasākumu rīkošanu. Bez visa minētā jāatzīmē, ka laikrakstā “Tēvija” publicētajās reklāmās un sludinājumos, lai arī nedaudz, tomēr atspoguḷojās arī laikmeta politiskās norises - nacistu okupācijas varas propaganda un nacistu ekonomiskā politika okupētajā Latvijā.

Par katras minētās sludinājumu grupas nozīmīgumu liecina arī tās īpatsvars pārējo sludinājumu vidū. Šeit gan jān,em vērā fakts, ka noteikt pilnīgi precīzu katras grupas sludinājumu skaitu ir grūti tādēl, ka vairums sludinājumu tēmu pārklājas, piemēram, sludinājumi, kur vācu okupācijas varas pārstāvji meklē dzīvojamās platības, iekḷaujas saimnieciskās dzīves vajadzībām veltīto sludinājumu klāstā. Tomēr ir iespējams noteikt aptuvenu rakstā aplūkoto sludinājumu grupu īpatsvaru. Sludinājumi, kuros radinieki meklēja padomju varas laikā vai karā bojāgājušos, dominē perioda sākumā - 1941. gada jūlija pirmajā pusē. Savukārt kultūras dzīvei veltīto sludinājumu skaits ir mazs perioda 
sākumā, bet vēlāk pieaug līdz apmēram trešdaḷai no kopējā sludinājumu skaita. Saimnieciskajai dzīvei veltīto sludinājumu skaits ir vislielākais, vairāk nekā puse visu sludinājumu, un tajos iekḷaujas arī rakstā aplūkotās tēmas - dzīvokḷu jautājums, preču deficīta radīto problēmu risināšana u. c.
Var secināt, ka lielākā dạ̣a sludinājumu nacistu okupācijas laikā liecina par cilvēku ikdienas dzīves problēmām, tomēr daudz uzmanības veltīts arī specifiskiem jautājumiem - upuru pieminēšanai, bojāgājušo meklēšanai, okupācijas varas politikas ietekmei ikdienas dzīvē; tas liecina, cik nozīmīgas šĩs tēmas bijušas iedzīvotāju ikdienā.

\section{ATSAUCES UN SKAIDROJUMI}

${ }^{1}$ Sludinājumus un reklāmas arī citur pasaulē kā vēstures avotus izmanto reti, tomēr atsevišķos gadījumos tie ir ḷoti nozīmīgi kādas vēstures problēmas izpētē, piemēram, analizējot ASV verdzības vēsturi, būtisks avots ir sludinājumi 18.-19. gadsimta laikrakstos par izbēgušo vergu meklēšanu. Sk., piemēram, Databases of Runaway Slave Advertisements. In: U. S. History: Primary Source Collections Online. Pieejams: https://shsulibraryguides.org/c.php?g $=86715 \& \mathrm{p}=558455$ (skatīts 25.09.2019.).

${ }^{2}$ Daina Bleiere, Ilgvars Butulis, Inesis Feldmanis, Aivars Stranga, Antoniss Zunda. Latvija Otrajā pasaules karā (1939-1945). Rīga 2008.

${ }^{3}$ Edvīns EvarTS, JuRIS PAVLovičs. Ikdienas dzīve Latvijā nacistiskās Vācijas okupācijas laikā 1941-1945. Rīga 2016.

${ }^{4}$ KASPARS ZELLIS. Ilūziju un baiḷu mašinērija. Propaganda nacistu okupētajā Latvijā: vara, mediji un sabiedrība (1941-1945). Rīga 2012.

${ }^{5}$ OJĀRS SKUDRA (red.). Latvijas preses vēsture: diskursi un identitātes. Rīga 2010.

${ }^{6}$ DMITRIJS OL̦EHNOviČs. Karikatūra kā "kara ierocis": dažas tendences nacionālsociālistiskajā propagandā. In: DZINTARs ĒRGLIS (sast.). Latvija nacistiskās Vācijas okupācijas varā, 1941-1945. Rìga 2004 (Latvijas Vēsturnieku komisijas raksti, 11), 30.-39. lpp.

${ }^{7}$ ARTURS ŽviNKLIs. Latviešu prese nacistiskās Vācijas okupācijas laikā. In: DAINA BLEIERE, IVETA ŠĶINĶE (sast.). Latvija Otrajā pasaules karā: starptautiskās konferences materiāli, 1999. gada 14.-15. jūnijs. Rīga 2000 (Latvijas Vēsturnieku komisijas raksti, 1), 353.-359. lpp.

${ }^{8}$ KASPARS ZELLIS. Latviešu prese Kurzemē, 1944./45. gads. In: Starptautiska zinātniskā konference "Otrā pasaules kara beigas Kurzemē - zināmais, aizmirstais, pētāmais" Liepājā 2005. gada 14. aprīlī. Liepāja 2005, 25.-27. lpp.

${ }^{9}$ LEO DRIBINS. Antisemītisms nacistiskās okupācijas laikā izdotajā presē Latvijā (1941-1945). In: BLEIERE, ŠĶIŅ̧̧E, Latvija Otrajā pasaules karā, 360.-371. lpp.

${ }^{10}$ DIDZIS BĒRZıN̦Š. Latviešu identitātes konstrukcija laikraksta "Tēvija" propagandas materiālos: "mēs un vinii" diskurss (1941. gada jūlijs - 1942. gada februāris). In: SKUDRA, Latvijas preses vēsture: diskursi un identitātes, 123.-143. lpp.

${ }^{11}$ DIDZIS BĒRZIN̦Š. Nacistiskā antisemītisma propaganda laikrakstā "Tēvija” 1941. gada jūlijā: latviešu (līdz)dalības diskurss. In: Latvijas Arhīvi 2009, Nr. 4, 63.-98. lpp.

12 KASPARS ZELLIS, DMITRIJS OL̦EHNOviČs. Laikraksta "Tēvija” karikatūras kā nacistiskā okupācijas režìma propagandas līdzeklis (1941-1941). In: Latvijas Vēsture 2005, Nr. 1, 47.-65. lpp.

${ }^{13}$ KASPARS ZELLIS. Vācu okupācijas sākumposmā 1941. gadā laikrakstā "Tēvija" publicēto lirikas darbu statistiskā analīze. In: HEINRIHS STRODS (zin. red.). Latvijas Okupācijas muzeja gadagrāmata 2005. Atbrīvotāji kā iekarotāji. Rìga 2006, 36.-49. lpp. 
${ }^{14}$ Piemēram, "Nacionālās enciklopēdijas" interneta mājaslapas šḳirklī "Reklāma un sabiedriskās attiecības Latvijā" reklāmas vēsture Latvijā raksturota šādi: "Reklāma kā apmaksāts pakalpojums parādījās, jau sākot ar Latvijas valsts atzī̌sanu pirms simt gadiem. [...] Galvenais, ko reklāmdevēji centās publicēt, bija reklāmas teksts, ko reizēm papildināja arī ilustrācija. Šo periodu var uzskatīt par reklāmas sludinājumu izvietošanas radošo risinājumu sākuma posmu." Tālāk aplūkota reklāmas vēsture Latvijā 20. gadsimtā, bet neskarot nacistiskās okupācijas posmu. Nacionālā enciklopēdija. Pieejams: https://enciklopedija.lv/skirklis/5166 (skatīts 23.08.2019.).

${ }^{15}$ Norādījumi par propagandas izmantošanu "Barbarosas" variantā. Berlīne, 1941. gada jūnijs. In: VILIS SAMSONS (sast.). Latvijas suverenitātes ideja likten,griežos. Vācu okupācijas laika dokumenti 1941-1945. Rīga 1990, 32. lpp.

${ }^{16}$ RSHA IV pārvaldes (gestapo) priekšnieka H. Millera ziņojums. Ziņojums par notikumiem PSRS. Nr. 53. Berlīne, 1941. gada 15. augusts. In: SAMSONS, Latvijas suverenitātes ideja liktengriežos, 38. lpp.

${ }^{17}$ Directive of the Wehrmacht Propaganda Section in Riga (Propagandastaffel Riga) about permission to distribute periodicals and magazines. In: ANDREJS PLAKANS (ed.). Experiencing Totalitaranism. The Invasion and Occupation of Latvia by the USSR and Nazi Germany 1939-1941. A Documentary History. Bloomington 2007, p. 108.

${ }^{18}$ Edgars ANDERSONS, LeONīDS Silin̦š. Latvijas Centrāāā Padome LCP. Latviešu nacionālā pretestības kustība 1943-1945. Upsala, 1994, 27. lpp.

${ }^{19}$ Latviešu periodika. Bibliogrāfisks rādītājs. 4. sēj. 1940-1945. Rīga 1995, 39. lpp.

${ }^{20}$ Ibidem, 95.-96. lpp.

${ }^{21}$ Ibidem, 125. lpp.

${ }^{22}$ Latvijas Padomju enciklopēdija, 5.2 sēj. Rīga 1984, 222. lpp.

${ }^{23}$ HEINRIHS STRODS. Latvijas pirmās padomju okupācijas aktīvistu vajāšanas (1941. gada 23. jūnijs - 1945. gads). In: DZINTARS ĒRGLIS (sast.). Okupētā Latvija 20. gadsimta 40. gados. Latvijas Vēsturnieku komisijas 2004. gada pētỉjumi. Rīga 2005 (Latvijas Vēsturnieku komisijas raksti, 16), 106.-204. lpp., šeit 184. lpp.

${ }^{24}$ Piemēram, 1941. gada oktobrī vācu karaspēks no Latvijas izveda preces un resursus 5644 439,97 reihsmarku apmērā, bet citām Vācu Reiha vajadzībām - preces un resursus 2906 480,85 reihsmarku vērtībā; novembrī attiecīgi 8891 956,59 un 343 366,04, decembrī - 9543 884,41 un 449 608,92 reihsmarku vērtībā. Sk. Kopsavilkums par piegādēm 1941. gadā reihsmarkās (RM). In: ElMĀRs PELKAUSS (red.). Okupācijas varu politika Latvijā 1939-1991. Dokumentu krājums. Rìga 1999, 196. lpp.

${ }^{25}$ Ostlandes reihskomisāra H. Lozes 1941. gada 18. augusta rīkojums par Ostlandes civilpārvaldes pārṇemšanu. In: PELKAUSS, Okupācijas varu politika Latvijā 1939-1991, 174. lpp.

${ }^{26}$ Vairāk par nacistu okupācijas varas kultūrpolitiku sk. DAINA BLEIERE, ILGVARS BUTULIS, INESIS Feldmanis, Aivars Stranga, ANTONiJs Zunda. Latvijas vēsture 20. gadsimts. Rīga 2005, 275.-283. lpp.; BLEIERE et al., Latvija Otrajā pasaules karā (1939-1945), 300.-312. lpp.

${ }^{27}$ Tēvija, 03.07.1941., 4. lpp.

${ }^{28}$ Ibidem.

${ }^{29}$ Tēvija, 05.07.1941., 1.-6. lpp.

${ }^{30}$ Tēvija, 07.07.1941., 6. lpp.

31 Tēvija, 05.08.1941., 5.-6. lpp.

32 Tēvija, 14.07.1941., 7. lpp.

${ }^{33}$ Tēvija, 11.08.1941., 6. lpp.

${ }^{34}$ Tēvija, 14.07.1941., 6. lpp.

35 Tēvija, 23.08.1941., 6. lpp.

${ }^{36}$ Tēvija, 11.12.1941., 4.-7. lpp. 
${ }^{37}$ Tēvija, 27.12.1941., 4. lpp.

${ }^{38}$ Tēvija, 05.08.1941., 5. lpp.

${ }^{39}$ Tēvija, 24.07.1941., 8. lpp.

${ }^{40}$ Tēvija, 11.08.1941., 6. lpp.

${ }^{41}$ Tēvija, 27.12.1941., 4. lpp.

${ }^{42}$ Tēvija, 12.07.1941., 6. lpp.

${ }^{43}$ Tēvija, 24.12.1941., 7. lpp.

${ }^{44}$ Tēvija, 19.07.1941., 8. lpp.

45 Tēvija, 24.07.1941., 7. lpp.

${ }^{46}$ Tēvija, 08.11.1941., 10. lpp.

47 Tēvija, 01.11.1941., 4. lpp.

${ }^{48}$ Tēvija, 04.09.1941., 7. lpp.

${ }^{49}$ Tēvija, 03.07.1941., 4. lpp.

${ }^{50}$ Tēvija, 25.07.1941., 7. lpp.

${ }^{51}$ Tēvija, 27.12.1941., 5. lpp.

${ }^{52}$ Tēvija, 22.08.1941., 7. lpp.

${ }^{53}$ Tēvija, 10.09.1941., 7. lpp.

${ }^{54}$ Tēvija, 21.10.1941., 5. lpp.

${ }^{55}$ Tēvija, 08.12.1941., 4. lpp.

${ }^{56}$ Tēvija, 03.07.1941., 4. lpp.

${ }^{57}$ Tēvija, 09.10.1941., 4. lpp.

${ }^{58}$ Tēvija, 25.07.1941., 7. lpp.

${ }^{59}$ Tēvija, 01.11.1941., 5. lpp.

${ }^{60}$ Tēvija, 09.10.1941., 4. lpp.

${ }^{61}$ Tēvija, 27.12.1941., 4. lpp.

${ }^{62}$ Tēvija, 20.09.1941., 5. lpp.

${ }^{63}$ Tēvija, 06.12.1941., 5. lpp.

${ }^{64}$ Tēvija, 28.08.1941., 7. lpp.

${ }^{65}$ Tēvija, 26.11.1941., 5. lpp.

${ }^{66}$ Tēvija, 02.12.1941., 5. lpp.

${ }^{67}$ Tēvija, 19.07.1941., 7. lpp.

${ }^{68}$ Tēvija, 07.07.1941., 5. lpp.

${ }^{69}$ Tēvija, 22.08.1941., 6. lpp.

${ }^{70}$ Tēvija, 27.09.1941., 5. lpp.

${ }^{71}$ Tēvija, 12.12.1941., 7. lpp.

${ }^{72}$ Visām filmām, par kurām bija iespējams atrast informāciju, filmas režisors, uzṇemšanas gads un sižets îsumā norādīti piezīmēs. Ja pamattekstā nav minēta filmas uzn̦emšanas valsts, tā ir filmēta Vācijā.

${ }^{73}$ Tēvija, 14.07.1941., 4. 1pp.

${ }^{74}$ Filmu nosaukumi saglabāti tādi, kā norādīts attiecīgajos sludinājumos. Jāṇem vērā, ka, latviskojot ārzemju filmu nosaukumus, tika piel̦auta visai brīva interpretācija. Šeit un turpmāk pamattekstā filmu nosaukumi atbilst attiecīgajiem sludinājumiem, oriǵinālie nosaukumi norādīti piezīmēs.

${ }^{75}$ Tēvija, 25.07.1941., 6. 1pp. 
${ }^{76}$ Režisora Veita Harlana (Veit Harlan) filma "Žĩds Zīss” (Jud Süß), uzṇemta 1940. gadā.

77 Tēvija, 16.08.1941., 5. lpp.

${ }^{78}$ Režisora Veita Harlana (Veit Harlan) filma "Mūsu Zēni” (Jugend), uzṇemta 1938. gadā. Sižets jaunatnes dzīve Vācijā.

${ }^{79}$ Režisora Valtera Rutmaņa (Walter Ruttmann) filma "Vācijas ieroču kaltuves" (Deutsche Waffenschmieden), uzṇemta 1940. gadā. Sižets - vācu militārā rūpniecība.

${ }^{80}$ Tēvija, 27.10.1941., 5. lpp.

${ }^{81}$ Režisora Bernda Hofmaņa (Bernd Hofmann) filma "Kad vīri aizcel̦o" (Fahrt ins Leben), uzṇemta 1940. gadā. Sižets - stāsts par vācu karaflotes kursantiem.

82 Tēvija, 12.07.1941., 5. lpp.

${ }^{83}$ Režisora Vilija Frosta (Willi Frost) filma "Mīlulis" (Bel Ami), uzṇemta 1939. gadā.

${ }^{84}$ Režisora Eduarda fon Borsodija (Eduard von Borsody) filma "Kongo ekspresis" (Kongo-Express), uzñemta 1939. gadā.

${ }^{85}$ Tēvija, 18.08.1941., 5. lpp.

${ }^{86}$ Karla Bēzes (Carl Boese) filma "Kāzu nakts" (Hochzeitsnacht), uzñemta 1940. gadā.

${ }^{87}$ Režisora Vladimira Slavinska (Vladimír Slavínský) komēdija “Julika” (Pritelkyne pana ministra), uzñemta Bohēmijas un Morāvijas protektorātā 1940. gadā.

${ }^{88}$ Režisora Hovarda Hoksa (Howard Hawks) komēdija "Pagājušās nakts meitene" (His Girl Friday), uzṇemta 1940. gadā.

${ }^{89}$ Austriešu režisora E. V. Emo (Emeriha Jozefa Vojteka; E. W. Emo, Emerich Josef Wojtek) filma "Mīlu nemuito" (Liebe ist zollfrei), uzṇemta 1941. gadā.

${ }^{90}$ Režisora Gēzas fon Bolvāri (Géza von Bolváry) komēdija "Operas balle” (Opernball), uzṇemta 1939. gadā.

${ }^{91}$ Tēvija, 15.09.1941., 7. lpp.

${ }^{92}$ Režisora Karla Bēzes (Carl Boese) mūzikls "Hallo, Janine” (Hallo Janine!), uzṇemts 1939. gadā.

${ }^{93}$ Režisora Viktora Turjanska (Viktor Tourjansky) filma "Nevainīgā mị̄āāā" (Die keusche Geliebte), uzñemta 1940. gadā.

${ }^{94}$ Režisora Milo Harbiča (Milo Harbich) detektīvfilma "Kriminālkomisārs Eiks" (Kriminalkommissar Eyck), uzņemta 1940. gadā.

${ }^{95}$ Dokumentālā filma par inuītu dzīvi.

${ }^{96}$ Režisora Karla Frēliha (Carl Froelich) komēdija "Neskati vīru no cepures" (Der Grassmann), uzñemta 1941. gadā.

${ }^{97}$ Režisora Karla Antona (Karl Anton) mūzikls "Deju virpulī” (Wir tanzen um die Welt), uzṇemts 1939. gadā.

${ }_{98}$ Tēvija, 22.09.1941., 6. lpp.

${ }^{99}$ Režisora Herberta Zelfina (Herbert Selphin) piedzīvojumu filma "Pandūrs Trenks" (Trenck, der Pandur), uzņemta 1940. gadā.

${ }^{100}$ Režisora Džo Stekela (Joe Stöckel) filma "Ciema mūzika” (Das sündige Dorf), uzņemta 1940. gadā.

${ }^{101}$ Tēvija, 25.07.1941., 6. lpp.

102 Tēvija, 31.07.1941., 7. lpp.

${ }^{103}$ Tēvija, 25.08.1941., 7. lpp.

${ }^{104}$ Tēvija, 26.11.1941., 4.-5. lpp.

105 Tēvija, 02.12.1941., 5. lpp.

106 Tēvija, 31.07.1941., 7. lpp.

${ }^{107}$ Tēvija, 26.09.1941., 4. lpp. 
108 Tēvija, 25.07.1941., 7. lpp.

109 Tēvija, 02.10.1941., 5. lpp.

110 Tēvija, 01.11.1941., 5. lpp.

\section{SUMMARY}

The purpose of the article is to analyse the classifieds and advertisements published in 1941 in Têvija, the official Nazi occupation power newspaper in Latvia, as history sources. In total, more than 34000 classifieds were published in the newspaper during that time period.

The approach that aims to study classifieds as historical sources can grant valuable insights into the history of the Nazi occupation period in Latvia. The classifieds can be divided into several subsections. The first group comprises the classifieds that have a direct link to the political events of the time period. These include the funeral announcements of those killed during the Soviet era posted by their relatives, as well as classifieds announcing search for relatives lost and missing due to the Soviet occupation and the war. The few classifieds posted by Nazi authorities, occasionally serving propaganda functions also fall into this category.

The second group comprises the classifieds reporting on the economic conditions of the time period, for instance, those related to housing. Buildings in Riga and other cities had been severely damaged during the Soviet occupation. The warfare in 1941 caused even more serious damage. Furthermore, as Latvia came under the Nazi occupation, part of the available premises was handed over to the occupation army and officials. Consequently, the need to find a living space was very urgent for many inhabitants of Latvia.

Another typical economic problem that can also be traced through the classifieds is the lack of many goods and materials. The extensive socio-economic experiments initiated by the Soviet occupation power had largely destroyed the traditional system of production and trade of Latvia, causing an acute shortage of various commodities. The Nazi occupation power began the transformation of the Latvian economy in accordance with the requirements of Nazi ideology. Hence, already during the first days of the occupation, the Latvian economy was adapted to serve the military purposes of the occupation regime, consuming a considerable amount of resources previously available for the general population.

The third economic topic addressed in the classifieds was the demand for workforce. In 1940-1941, both Soviet and Nazi terror and warfare significantly reduced the population of Latvia. As a result, recruitment classifieds became highly topical, thus also revealing the proof of the economic policy of the Nazi occupation power in the invaded territories, where the main purpose was to maximize the use of resources for the needs of the army.

In addition to the above, there is a significant amount of advertisements placed in Têvija that can be related to the group advertising "cultural events". First of all, there are announcements of entertainment and social events. They provide an insight into the range of activities available to the Latvian population despite the warfare. The advertisements announcing the repertoire of Latvian cinemas and theatres can be referred to as a particular subgroup, as they allow to assess the influence of Nazi propaganda to the repertoire contents. Another subgroup comprises the advertisements directly related to the Nazi regime - for example, inviting to purchase Nazi propaganda materials. 